\title{
THE DISSEMINATION OF TECHNOLOGY-BASED LEARNING MEDIA FOR ELEMENTARY SCHOOL TEACHERS IN THE DISTRICT OF SIJUNJUNG
}

\author{
Irfandi $^{1 *}$, Faisal ${ }^{2}$, Novita Indah Hasibuan ${ }^{3}$, Deo Demonta Panggabean ${ }^{1}$ \\ ${ }^{1}$ Department of Physics, Faculty of Math and Science, Medan State University, Medan, Indonesia \\ ${ }^{2}$ Department of Primary Teacher Education, Faculty of Science Education, Medan State University, Medan, \\ Indonesia \\ ${ }^{3}$ Department of Economic Education, Faculty of Economics, Medan State University, Medan, Indonesia \\ *Corresponding Author: irfandi@unimed.ac.id
}

\begin{abstract}
The purpose of this program is to improve the ability and skills of teachers on the use of learning media of science in the elementary school (known as Sekolah Dasar in Bahasa; henceforth abbreviated as SD) at the district of Sijunjung in the province of Sumatera Barat, Indonesia. We encouraged respective teachers on modifying, creating and using learning media relevant to Science learning in SD. Thus, teachers are not only able to utilize the existing science learning media, but also to develop new learning media related to the subject. The output of the program is the guidebook that teachers can further use as a technical guideline in applying science learning media at SD. In assuring the quality of the program, the evaluation was conducted through process and result assessments. The mean score of 3.54 and 3.73 rooted from process and result assessments respectively indicating the performance of teachers applying science learning media at a very good category. In conclusion, the dissemination program of technology aids learning media science in elementary school teachers in the District of Sijunjung at the Province of West Sumatra was successfully implemented.
\end{abstract}

Keywords: Science, Learning Media, Elementary School, Sijunjung, Sumatera Barat

\section{INTRODUCTION}

The success of the learning process at every level including Elementary School (SD) is highly dependent on the availability and quality of teachers is adequate. The reality in the field shows that the availability of facilities and infrastructure, especially in the elementary school still needs revamping. Similarly, the quality of teaching teachers who on average still not adequate (less quality). When we refer to the nature of Natural Science (IPA), learning is not classically appropriate. Fisher (in Amien, 1987) states that IPA is a collection of knowledge gained through observation. Amien (1987), explains that the growing IPA generally undergoes different phases, namely: (1) obsevation, (2) classification, and (3) experimentation. Similarly, the demands of the science curriculum on the curriculum of KTSP and the 2013 curriculum, almost all subjects of science, are taught by using teaching methods accompanied by simple experiments.

Based on the above explanation, obtained the picture that science learning can not be separated from the observation activities of IPA symptoms are taught. Observation activities are part of the activities of simple experiments that are absolutely necessary. Thus the importance of observation activities for students, Carin (in Subiyanto, 1988) states that laboratory activities are inseparable activities in teaching science. This means that the laboratory (although the laboratory is still limited to simple IPA tools) is one of the main conditions for implementing science teaching according to the nature of the science itself.

Referring to the above problem, it should be the process of science learning in SD done by using simple experiments. Simple experiments can be performed using props that are in accordance with science lessons in SD. This certainly has a major impact on the direct experience of students in finding concepts taught by teachers in elementary school. However, based on observations and interviews conducted on 18-20 July 2017 at SD Negeri 04 Sibakur and SD Negeri 03 Langki Sijunjung Regency West Sumatra Province, the process of science learning has not been done with simple experiments. Some of the problems found can be detailed as follows.

First, the implementation of science learning process in the classroom is generally done by conventional methods of lecture and tutorial methods. Such learning methods make students tend to get bored and less interested in following the learning process. Thus, the learning process has not run effectively in accordance with the expected learning objectives. This is marked by the lack of understanding of students' concepts of the material being taught. In addition, 
student learning outcomes are still relatively low because many have not reached the minimum Minimum Criterion determined, ie 65 .

Secondly, some teachers are already using the science learning medium in the classroom but not maximally in its use. Stages and procedures for the utilization of the media are less understood by the teacher so that the understanding of the concept of the utilization of the media used is poorly understood by the students. Based on question and answer with some teachers, there are some media of science teaching in school, but the manual how to use it does not exist. Thus, teachers do not understand how to use and if used only with a limited understanding of teachers to the media. Learning media are widely used only limited to the drawings related to learning materials.

Third, the training activities undertaken by the KKG are only theoretical and less operational. Such training makes teachers rich in conceptual understanding but less able to apply concepts they understand. Thus, the training undertaken in the KKG is less perceived by teachers.

Fourth, from teacher factor aspect, it is found that from 19 teachers, there are 12 teachers who are elderly and less productive. However, with the existence of 7 young teachers, it is still possible to improve teachers' productivity in developing and utilizing effective learning media of IPA in the learning process.

In response to the above problems, it is necessary to reform the learning paradigm as an effort to achieve the optimization of science learning process in elementary school. One of the efforts that can be done is to guide and guide teachers in designing and using a variety of simple teaching aids in SD. In this way, teachers are expected not only skilled in designing IPA props, but are actually capable of utilizing IPA aids in the learning process. Finally, the concepts to be achieved in science learning will be well understood by the students as they learn through the process and direct experience using the designed IPA props. Based on the above explanation, Institute of Community Service (LPM) State University of Medan (Unimed) implement a program devotion with the title of "The Dissemination of Technology-Based Learning Media for Elementary School Teachers in The District of Sijunjung”.

\section{TOOLS, MATERIALS, AND METHODS OF IMPLEMENTATION OF ACTIVITIES TOOLS AND MATERIALS}

In the execution of this activity required some equipment that is easy to get around, as well as materials classified as waste that can be used as learning media such as, waste plastic bottle, carton, plastic, wire, scissors, galvanometer, magnet and other waste.

\subsection{Activity Implementation Method}

The parties involved in this program are IPA teachers in schools consisting of 27 units of basic education covering 1 Madrasah Ibtidaiyah (MI), 1 SDIT and 26 SD Negeri. which are all incorporated in the sub-Rayon Regional Technical Services Unit (UPTD) Tanjung Gadang District. Most of the basic institutions in Tanjung Gadang sub-district are still accredited $\mathrm{C}$ including in both Partner Schools and there are still schools not yet accredited. The number of elementary school teachers in Tanjung Gadang is 259 teachers consisting of 94 Men and 165 Women with ratio between teacher and student 1: 13. In addition, some teachers $17 \%$ or 43 teachers have not met S1 or D4 qualification, most are D1 up to D3 and the number is mostly found in partner schools namely SD Negeri 03 Langki and SD Negeri 04 Sibakur.

Teachers who have not fulfilled the Strata 1 qualification at Sekolah Mitra SD Negeri 03 Langki and SD Negeri 04 Sibakur Tanjung Gadang Subdistrict Sijunjung Regency, this will be a priority to get training and facilitation of dissemination of learning media technology from the materials that exist around. In addition to teachers and schools, other parties involved are the District Education Office of Tanjung Gadang, which is an authorized official who accompanies the school and teachers and the process of providing participants. District Government of Tanjung Gadang which is the host of a series of training and facilitation activities dissemination of learning media technology from the materials that exist around. In addition, members of the Legislature who have a high concern and concern with the development of education in Sijunjung district of West Sumatra province.

\subsection{Methods Used In Solving Partner Problems}

The method used in the implementation of this activity is training and mentoring the use of media in the process of learning in class. Training is conducted by collecting science teachers from each school to obtain materials and materials and modules that they can use both during the training and in the mentoring process.

1) For more details in reading the scheme above activities can be described as follows: Preliminary Observations Partner Locations conducted before the program is run aims to find out the various problems that kompeherenship faced by partners.

2) Make agreement and justification problem solving with partners this is done to determine alternative solution of teacher in solving the problem 
3) Practice mentoring in the preparation of RKBM (Teaching and Learning Activity Plan) tailored to the program being run

4) Designing science learning media or tools by manifesting natural materials and waste, in accordance with the RKBM prepared

5) Practical training activities using science learning medium or media by manipulating natural materials and waste as learning aids

6) Simulation of the use of learning tools or learning media by consuming natural materials and waste as a tool for learning media in front of the classroom.

7) Oven class teaching practice by teachers in the classroom by using the tools or learning media IPA by manifting natural materials and waste as a medium of learning witnessed by students and teachers-colleagues

8) Evaluate the process and evaluate the results. Evaluate the process using process instruments and instrument activities while evaluating the results using tests

9) Follow-up from this activity is seen from the success in learning effectiveness as well as the value of the test. If you experience success will be done with the next material.

Special equipment that is difficult to obtain, during the training process the teacher will get from the organizing committee so that in the application of learning process in school did not experience any constraints. During the training process teachers are grouped and competed between groups so that a good competition among the teachers is expected to emerge. The mentoring process is done by assisting teachers directly in class in applying the knowledge that has been obtained during the training so that it can be given input directly to each teacher after completion of learning. The evaluation results are expected to be improved in the next learning process by assisting the class.

\subsection{Work Procedures In Support Of Realization Of The Methods Offered}

In order for the working procedure to support the realization of the methods offered in the above scheme readings can be described as follows:

1) Preliminary Observations Partner Locations conducted before the program is run aims to find out the various problems that kompeherenship faced by partners.

2) Make agreement and justification problem solving with partners this is done to determine alternative solution of teacher in solving the problem

3) Practice mentoring in the preparation of RKBM (Teaching and Learning Activity Plan) tailored to the program being run

4) Designing science learning media or tools by manifesting natural materials and waste, in accordance with the RKBM prepared

5) Practical training activities using science learning medium or media by manipulating natural materials and waste as learning aids

6) Simulation of the use of learning tools or learning media by consuming natural materials and waste as a tool for learning media in front of the classroom.

7) Oven class teaching practice by teachers in the classroom by using the tools or learning media IPA by manifting natural materials and waste as a medium of learning witnessed by students and teachers-colleagues

8) Evaluate the process and evaluate the results: Evaluate the process using process instruments and instrument activities while evaluating the results using tests

9) Follow-up from this activity is seen from the success in learning effectiveness as well as the value of the test. If you experience success will be done with the next material.

\section{THE RESULTS ACHIEVED}

\subsection{Activity Results}

The dissemination program of science learning medium aids technology in SD Sijunjung Regency of West Sumatera Province is done in several stages of activity, among others: (1) Preparation, (2) Implementation, (3) Evaluation, and (4) Follow Up. For more details, can be seen in the following description.

\section{1) Preparation}

Preparation stage is the first step of the program of technology dissemination dissemination of learning tools of science learning media in SD Kab. Sijunjung Prov. West Sumatra. Some of the activities undertaken in the preparation stage can be explained as follows.

\section{a) Initial Observation}

Preliminary observations to partner sites aim to identify the various comprehensive issues faced by partners. Preliminary observations were held on Tuesday s.d Thursday, 18 s.d 20th July 2017. The observations were held in several schools of Kecamatan Tanjung Gadang as the representation of SD Sijunjung District of West Sumatera Province. Preliminary observations were made through direct observation of the learning process in the classroom, especially in the science lesson and interviews with several class teachers in the primary schools visited. Through preliminary observations conducted, obtained the profile of partners to be provided assistance program 
dissemination technology learning aids science in the Sijunjung District of West Sumatera Province. The profile of partners who are targeted by the program of service based on the initial observation is all the elementary schools in Kecamatan Tanjung Gadang Sijunjung District of West Sumatera Province. The number of elementary schools that are involved in the service program are 25 primary and private elementary schools.

\section{b) Agreement on the Problems Faced}

Making a deal and justifying problem solving with partners is done to determine the teacher's alternative solution in solving the problem. Problems faced by teachers based on observation of the learning process in the classroom and interview can be explained as follows.

1) Teachers have not been able to formulate RKBM maximally according to the demand of science learning process effectively in SD

2) Teachers have not used the media/props in the process of learning science in the classroom.

3) Teachers have not been able to develop appropriate science learning media in science learning in elementary school.

4) Although the media pebelajaran already exist, teachers less than the maximum use of media in the process of learning in the classroom.

\section{c) Agreement on Solutions for Problem Solving}

Based on the problems agreed earlier, the following solutions are formulated to solve problems.

1) Assisting the preparation of RKBM, especially science learning at elementary level.

2) Assisting the making of tools/learning media in accordance with science lesson in elementary school.

3) Conducting simulation of science learning process in SD through peer teaching. With this activity, each participant is expected to give inputs in order to improve learning process using media / props in science learning in class.

4) Assisting the open class, so that teachers can apply directly the use of tools / media learning science in the class effectively.

\section{2) Implementation}

The implementation of the devotion program is conducted in two periods of activity with the first phase of training with focus on the content of learning tools. The first wave was held on Thursday s.d Saturday, 05 s.d 07 October 2017 and continued the second period was held on Thursday s.d Saturday, 02 s.d 04 November 2017. In general, the description of activities can be explained as follows.

In the first wave, the activities that have been done are grouped as follows: (1) mentoring of RKBM preparation practice, (2) designing learning tool/learning media, (3) practice of making learning tool/learning media, (4) simulation of learning tool/IPA in SD, and (4) open class in the form of real teaching utilization of learning tool/ learning media in SD. For more details, can be described as follows.

\section{a) Assistance Practice RKBM Preparation}

Assistance in the drafting practice of RKBM was conducted on Thursday, 05 October 2017. This activity started with the presentation of materials about the concept of RKBM and its components. Furthermore, the analysis of Competency Standards (SK) and Basic Competency (KD) of science lesson in elementary school. After analysis of SK and KD then formulated the design of the appropriate stages of activity in the process of achieving the SK and KD. In this activity, the teacher tries to formulate a different RKBM according to the distribution of KD previously given. The teachers seemed enthusiastic to follow the activities because they have understood the concept of RKBM and components contained therein. Not only that, RKBM designed by each participant is correct and in accordance with the demand of science learning process in SD. Thus, the assistance of making RKBM that has been done is very beneficial by teachers in order to create an effective learning process at class.
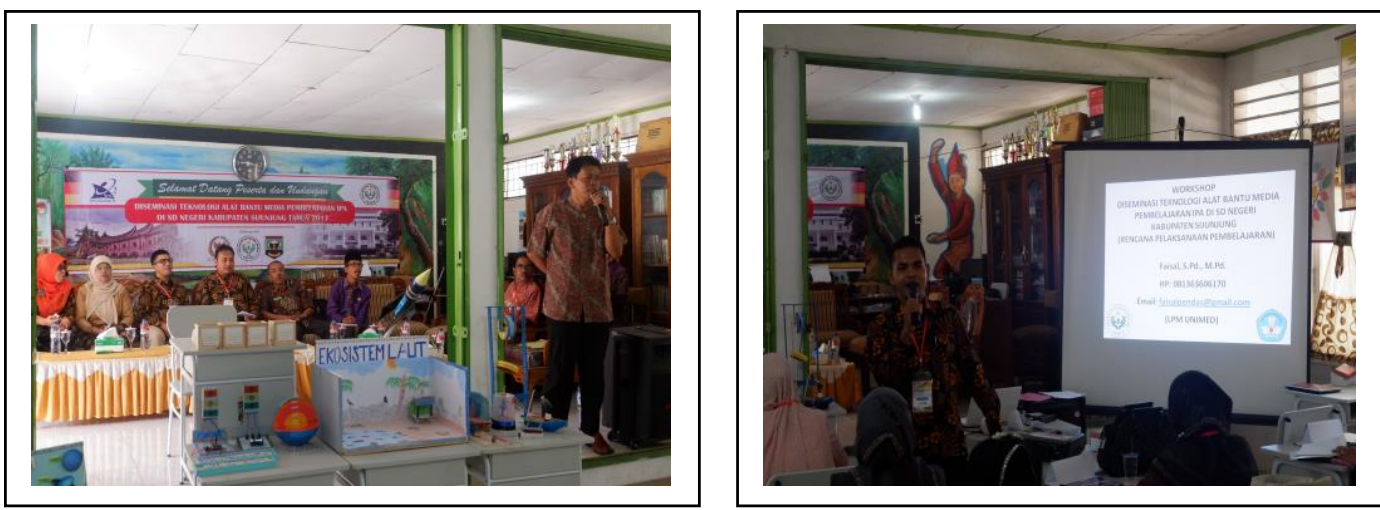

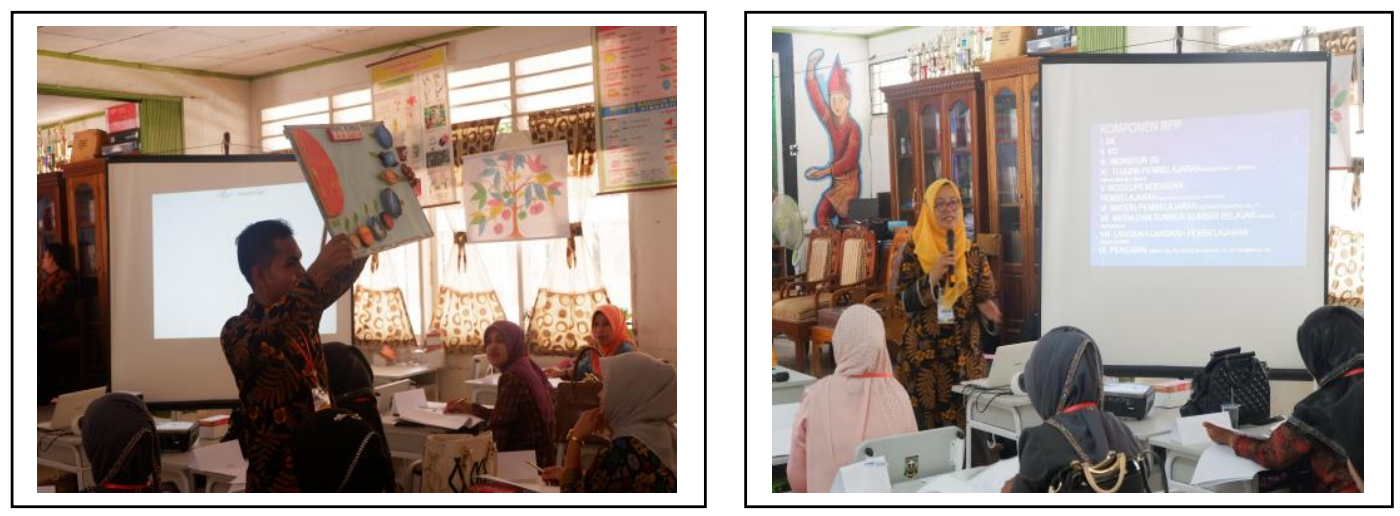

Figure 1. Activities Designing RKBM Science Learning in SD

\section{b) Designing Learning Tool/Media}

Designing tools/learning media IPA done after formulating RKBM. This activity was conducted on Thursday, 05 October 2017. The learning tools/ learning media of IPA will be tailored based on the result of SK and KD analysis on the previous activity. To maximize this activity, participants are grouped into 5 groups with 6 group members.

Initial stage of activity of designing tool/learning media of IPA done by material exposure by instructor about media/props appropriate with science learning process in elementary school. After an explanation of the various media that can be used in the process of science teaching in elementary school, the instructor then explains how to design the media/props are disclosed. The media/props to be designed are complemented by a pre-prepared manual of learning tools/learning media of IPA in SD. In the manual described the complete SK and KD to be achieved, the tools and materials needed, and instructions on how to manufacture the media/props to be designed.

The next stage, each participant is given the opportunity to read the prepared manuals and set media/props that will be designed in groups. However, in order for each group to have the same experience in designing the media / teaching aids in science SD, accompanied by the design of the same learning tool / media in each group. Thus, the description of the level of truth of the props has been designed in comparison with the work of the other groups.
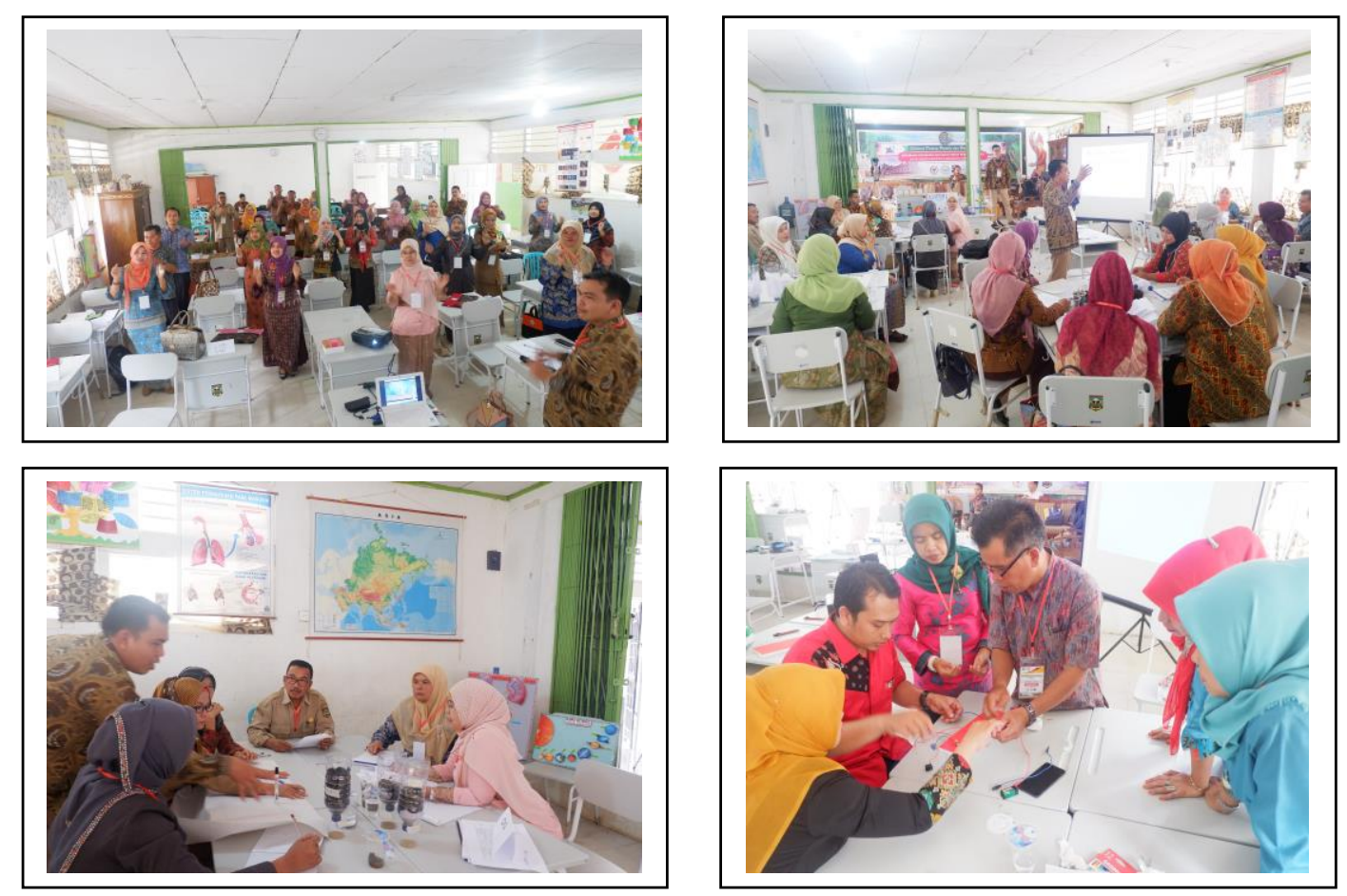

Figure 2. Media Designing Activities/Learning Tools in SD

\section{c) Practicum Training of Learning Tool/Media Utilization}

Practical training of media utilization/learning tool of science in elementary school is an advanced stage after media/props have been designed. This training was held on Friday, 06 October 2017. The media/props that have 
been designed need to be guided by effective way of utilization in the learning process in the classroom. It is intended that the teachers are not wrong to use media/props that have been designed in an effort to achieve the concept contained in SK and KD. This activity is conducted in the form of media trials/props that have been designed. After that, the participants give each other input to the product in the form of tools/learning media that has been designed by each group. The input provided is focused on the advantages, disadvantages, or insufficiency of the tool $/ \mathrm{medium}$ that each group has designed.

\section{d) Simulation of the Use of Science Equipment/Media In SD}

Teaching Simulation of the use of tools/learning media IPA is a pilot learning process in the form of peer teaching before doing the actual learning process in the classroom. learning simulation activities conducted on Friday, 06 October 2017. Through the simulation will be obtained input and suggestions from each participant associated with the view simulated by the model teacher. This input is then adopted by each model teacher in order to perfect the learning process when the open class in the form of real.

\section{e) Open Class}

Open Class is the core activity of technology dissemination program of media aids/teaching aids tool of science in Sijunjung district. This activity was conducted on Saturday, 07 October 2017. Open class activity was conducted at three point of elementary school determined by UPTD Kecamatan Tanjung Gadang, namely SD 01 Tanjung Gadang, SD 02 Tanjung Gadang, and SD 10 Tanjung Gadang. Open class activities are recorded in the form of learning videos. The results of this activity is a model teacher in the form of real teaching the utilization of tools/learning media IPA Simply.

\section{3) Evaluation}

\section{a) Process Evaluation}

Evaluation of the service program process, focused on several aspects, including: (1) pretrial performance, (2) training performance, (3) training effectiveness, and (4) impact on implementation. Based on the results of the analysis of the questionnaire filled by the trainees, given the evaluation process description as listed in table 1 below.

Table 1. Process Evaluation of Technology Dissemination Program Tool for Science Media Learning in SD

\begin{tabular}{|c|l|c|c|}
\hline No & \multicolumn{1}{|c|}{ Aspects Reviewed } & Average Qualification & Score \\
\hline 1 & Preliminary Performance & 3,27 & Good \\
\hline 2 & Training Performance & 3,71 & Very Good \\
\hline 3 & Training Effectiveness & 3,61 & Very Good \\
\hline 4 & Impacts While Training & 3,58 & Very Good \\
\cline { 1 - 2 } Number of & $\mathbf{1 4 , 1 7}$ & \multirow{2}{*}{$\mathbf{3 , 5 4}$} \\
\cline { 1 - 2 } Average & Very Good &
\end{tabular}

Based on table 1 above can be seen that the performance appraisal performance results are at an average of 3.27 with Good category. Assessment on training performance is on average 3.71 with Excellent category. The average assessment of training fetetivity was at 3.61 with the Excellent category. Assessment of the impact aspect during training was 3.58 on average with Very Good category. Simply put, if illustrated in the form of diagrams, evaluation of the service program process can be seen in Figure 3 below.

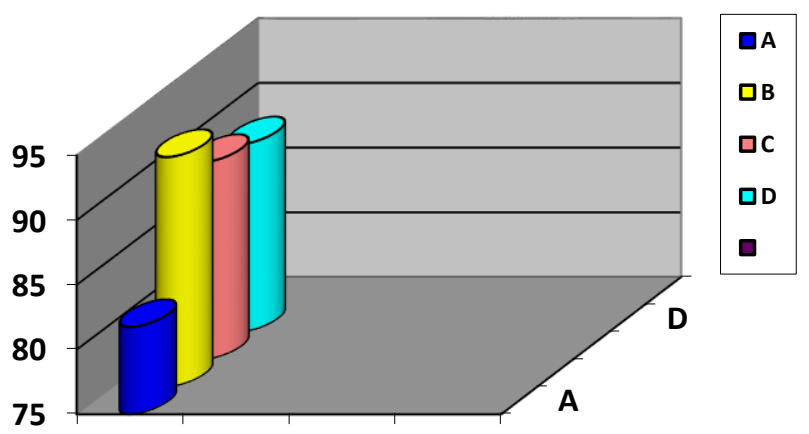

Figure 3. Evaluation of Technology Tool Dissemination Process Science Media in Elementary School 


\title{
Information:
}

A = Preliminary Performance

$\mathrm{B}=$ Training Performance

$\mathrm{C}=$ Training Effectiveness

$\mathrm{D}=$ Impact On Implementation

Based on table 1 and picture 3 it can be concluded that the process of dissemination program technology aids of learning media in science IPA Sijunjung district-West Sumatra was done very well. That is, the participants have a very good perception of the program devotion that has been implemented.

\section{b) Evaluation of Results}

The evaluation of the results of the dissemination program of the technology of learning aids in science learning media in SD Sijunjung District of West Sumatera Province is seen through several aspects, among others: (1) the usefulness of the activity, (2) the activities reflect the application of technology aids of learning media IPA, (3) (4) assignments help understanding, and (5) clarity provides an overview of classroom application. For more details can be seen in table 2 below.

Table 2. Results of Program Success Analysis of Service

\begin{tabular}{|c|l|c|c|}
\hline Number & \multicolumn{1}{|c|}{ Rated Aspect } & $\begin{array}{c}\text { Average } \\
\text { Score }\end{array}$ & Qualification \\
\hline 1 & Activity Empowerment & 3,97 & Very Good \\
\hline 2 & $\begin{array}{l}\text { Activity Reflects Technology Application of } \\
\text { Science Media Aids Tool }\end{array}$ & 3,70 & Very Good \\
\hline 3 & Mastery of Material & 3,87 & Very Good \\
\hline 4 & Assignment Helps Understanding & 3,90 & Very Good \\
\hline 5 & $\begin{array}{l}\text { Clarity Gives a View of Classroom } \\
\text { Implementation }\end{array}$ & 3,23 & Good \\
\hline & Amount & \multicolumn{2}{|c|}{$\mathbf{3 , 7 3 4}$} \\
\hline & Average & \multicolumn{2}{|c|}{ Very Good } \\
\hline
\end{tabular}

Based on table 2 above, obtained the picture that when viewed from the usefulness of activities, program devotion is at an average of 3.97 with very good category. When viewed from the activities reflect the application of technology learning tools IPA learning media obtained an average of 3.70 with very good category. Furthermore, when viewed from the mastery of the material, the mentoring program obtained an average of 3.87 with excellent qualifications. The average score of a devotional program when viewed from the assignment helps understanding is 3.90 with very good category. Then, the average score of program devotion when viewed from clarity gives an idea of application in the class is 3.23 with good category. The average score of the overall service program is 3,734 with very good category.Referring to Table 2 , the result of dissemination of technology tools of learning media of science in Sijunjung Regency can be seen in the following figure.

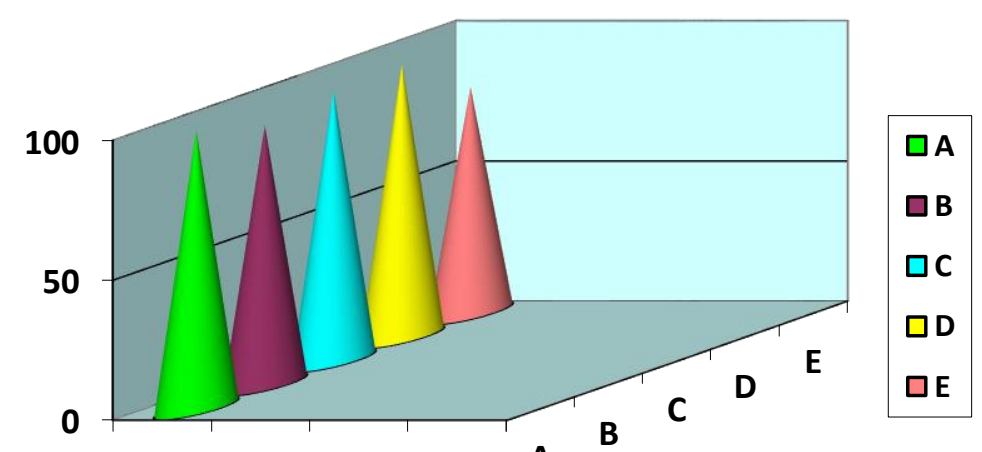

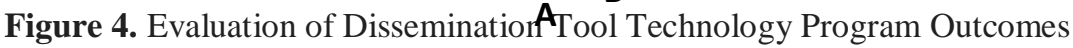
Science Media Learning in SD Sijunjung District

\author{
A = Activity Activity \\ $\mathbf{B}=$ Reflecting the Application of Science Aids Technique Media Tool \\ C = Mastery of Material \\ $\mathbf{D}=$ Assignment Helps Understanding \\ $\mathbf{E}=$ Clarity Gives a View of Classroom Implementation
}


Based on the above explanation, it can be concluded that the devotion program that has been done very useful and very good done especially in an effort to improve the competence of teachers in utilizing the tools/media learning science in elementary school.

\section{4) Follow Up}

Based on the results of previous evaluation, several follow-ups were conducted, among others:

a) Improving performance in modeling the application of media/teaching aids in science elementary school in the elementary so that the trainees really able to imitate well in an effort to improve the process of learning utilization of media/props IPA in elementary school optimally.

b) Disseminate technological tools of learning media on other subjects in elementary and wider area scopes.

\subsection{Achieved Outcomes}

Outcomes that have been achieved through technology dissemination program of teaching aids medium of science in elementary school of Sijunjung district-West Sumatra can be detailed as follows.

1) Handbook of making tools/learning media IPA in elementary school.

2) Various tools / media learning IPA in elementary school.

3) Teachers of the implementation model of the utilization of tools/learning media of science in elementary school.

4) Scientific articles published in the proceedings of international seminars of devotion to the community.

5) Publication on online mass media related to technology dissemination program of teaching aids medium of science in elementary school which has been implemented.

\section{THANK-YOU NOTE}

We would like to thank the government through the Directorate General of Research and Development of the Directorate General of Research and Community Service (DRPM) of the Ministry of Research and Technology of Higher Education of the Republic of Indonesia who has given us confidence to do Community Service of Fiscal Year 2017. Thank you also to say to the Rector of State University of Medan and Community Service Institute of Medan State University who help and guide us in carrying out this community service.

\section{REFERENCES}

Davidson, N., \& Worsham, T. (Eds.). 1992. Enhancing Thinking Throughcooperative Learning. New York, NY: Teachers College Press.

Ibrahim, M., Rachmadiarti,F., Nur, M.. 2007. Pembelajaran Kooperatif, Edisi ke-1. Surabaya: UNESAUniversity PRESS,

Menteri Pendidikan dan Kebudayaan, 2013. Peraturan Menteri Pendidikan dan Kebudayaan Republik Indonesia Nomor 65 Tahun 2013 tentang Standar Proses Pendidikan Dasar dan Menengah. Jakarta: Kemendikbud.

Nauli, R., dkk. 2006. Perbaikan Pembelajaran Anorganik I melalui Pengayaan Pada Pendekatan Pembelajaran Kooperatif dengan Bantuan Peta Konsep. Medan : FMIPA UNIMED Medan Laporan Teaching Grant.

Nauli, R., Jasmidi, Arbain. 2004. Upaya Peningkatan Interaksi dan Hasil Belajar siswa SMA Melalui Belajar Kooperatif Dengan menggunakan Media Peta Konsep dan Alat Peraga. Medan: FMIPA UNIMED Medan Laporan Penelitian PTK.

Panggabean, D. D., Irfandi, I., \& Sinuraya, J. 2017. Improving of The Student Learning in Lectures of General Physics I by Collaborative Learning Model Based on Saintific Approach. Jurnal Pendidikan Fisika Indonesia, 13(2), 94-101.

Panggabean, D. D., \& Irfandi, I. 2016. Peningkatan Aktivitas dan Hasil Belajar Mahasiswa Dengan Penerapan Model Pembelajaran Berdasarkan Masalah pada Mata Kuliah Fisika Umum I. JURNAL IKATAN ALUMNI FISIKA, 2(1), 44-49.

Riyanto, Y. 2010. Paradigma Baru Pembelajaran: Sebagai Referensi bagi Pendidik dalam Implementasi yang Efektif dan Berkualitas. Jakarta: Kencana.

Sanjaya, W. 2009. Strategi Pembelajaran Berorientasi Standar Proses. Jakarta: Kencana.

Slameto, 2003, Belajar dan Faktor-faktor yang Mempengaruhi. Jakarta: Rineka Cipta.

Slavin, R. 2005. Cooperative Learning Teori, Riset dan Praktik. Bandung: Nusa Media.

Sudrajat, A. 2008. Pengertian Pendekatan, Strategi, Metode, Teknik dan Model Pembelajaran. Bandung: Sinar Baru Algensindo.

Suyanti, R. 2010. Strategi Pembelajaran Fisika. Yogyakarta: Graha Ilmu.

Winkel, 1996. Psikologi Pengajaran. Jakarta: Gramedia Widiasarana Indonesia. 